FOLIA PRAEHISTORICA POSNANIENSIA T. XXI - 2016 INSTYTUT ARCHEOLOGII, UAM POZNAŃ - ISSN 0239-8524 http://dx.doi.org/10.14746/fpp.2016.21.05

\title{
VITIS VINI FERA SYLVESTRIS I VITIS VINIFERA SATIVA. UDOMOWIENIE I UPOWSZECHNIENIE SIE UPRAWY WINOROŚLI W STARYM ŚWIECIE NA PODSTAWIE BADAŃ ARCHEOLOGICZNYCH I PALEOBOTANICZNYCH
}

\author{
VITIS VINIFERA SYLVESTRIS AND VITIS VINIFERA SATIVA. \\ THE DOMESTICATION AND DISSEMINATION \\ OF VITICULTURE IN THE OLD WORLD BASED ON \\ ARCHAEOLOGICAL AND PALAEOBOTANICAL RESEARCH
}

\author{
Agnieszka Góralczyk \\ Instytut Archeologii i Etnologii Polskiej Akademii Nauk \\ al. Solidarności 105, 00-140 Warszawa, Poland \\ agnieszka785@gmail.com
}

\begin{abstract}
This paper looks at the domestication and spread of viticulture in the Old World and shows how useful is botanical research on the contemporary species of wild and cultivated vine for archaeology the paper presents the objectives and possibilities of archaeobotanical research.
\end{abstract}

KEY WORDS: vitis vinifera sylvestris, vitis vinifera sativa, wild vine, cultivated vine, cultivars, carbonation, archaeobotany, wine

\section{UDOMOWIENIE I POCZĄTKI UPRAWY WINOROŚLI (VITIS VINIFERA L.)}

Morfologiczne i genetyczne badania porównawcze pozwoliły zidentyfikować dziką roślinę, od której pochodzi winorośl właściwa uprawna (Vitis vinifera sativa), ściśle powiązaną ze współcześnie istniejącymi formami dzikimi: europejskimi i zachodnioazjatyckimi. Początkowo zaliczano ją do gatunku dzikiej winorośli właściwej leśnej (Vitis vinifera sylvestris), a obecnie do odmian jej podgatunku Vitis 
vinifera L. subsp. sylvestris, występujących powszechnie na południu Europy i w zachodniej Azji, czyli na obszarze rozciągającym się od atlantyckiego wybrzeża Hiszpanii i Francji do Tadżykistanu (Zohary 1996, s. 24).

Znaleziska paleobotaniczne i archeologiczne potwierdzają, że na obszarach obejmujących Bliski Wschód (od Iranu i Turkmenistanu do krajów Lewantu) oraz południową Europę w czasie cieplejszych faz plejstocenu i holocenu pojawiły się szczepy dzikiej winorośli i rozprzestrzeniły się najpierw na południu opisywanych terenów, a potem w kierunku północnym (Zohary 1996, s. 24-25).

Najlepsze obecnie warunki do rozwoju dzikiej winorośli stwarza łagodny i wilgotny klimat, charakterystyczny dla basenu Morza Śródziemnego oraz okolic lasów liściastych porastających południowe wybrzeża Morza Czarnego oraz obszary rozciągające się na południe i na zachód od Morza Kaspijskiego, północną Grecję i południowe Bałkany. Winogrona sylvestris występują we Włoszech, Francji, Hiszpanii i w Afryce Północnej, a także na niektórych obszarach Bliskiego Wschodu i Azji Środkowej (w wąwozach, w pobliżu strumieni) oraz w klimacie umiarkowanym: w Europie Środkowej, w dolinach Renu i Dunaju (w rozproszonych populacjach) (Renfrew 1996, s. 255; Zohary 1996, s. 24).

Dzika winorośl często rosła w pobliżu drzew lub krzewów, oplatając je i wspinając się ku górze, aby uzyskać jak największy dostęp do światła słonecznego, ponieważ jest to roślina kochająca słońce. Chociaż najlepszym miejscem do życia są dla niej otwarte tereny leśne występujące w basenie Morza Śródziemnego lub obrzeża najbardziej gęstych lasów na obszarach łęgowych, nie należy zapominać o jej możliwościach adaptacyjnych. Dzika winorośl potrafi przystosować się do bardzo różnych warunków i czasami rodzaj gleby lub obecność skał na określonym obszarze nie stanowi przeszkody, czego przykładem są śródziemnomorskie zarośla w bardzo suchych miejscach, gdzie można znaleźć opisywane rośliny (Bouby, Marinval 2001, s. 15).

Zasadniczym problemem $\mathrm{w}$ odtworzeniu mapy i etapów rozprzestrzeniania się dzikich form winorośli są trudności z rozróżnieniem odmian dzikich od udomowionych (Renfrew 1996, s. 255). Bardzo często na obszarach, na których winorośl sylvestris rośnie $\mathrm{w}$ bezpośrednim sąsiedztwie winnic $\mathrm{z}$ uprawną winną latoroślą, dochodzi do samoistnego krzyżowania się obu gatunków. Dzika winorośl zajmuje zwykle obrzeża upraw, opuszczone zagajniki, pobocza i podobnie sztuczne, wtórne siedliska. W wyniku krzyżówki tworzą się wówczas prawdziwie dzikie formy rosnące $\mathrm{w}$ pierwotnych siedliskach, pochodne powstałe w wyniku rozmnażania z nasion hybrydowych. Często odróżnienie dzikich form od ich pochodnych jest bardzo trudne lub wręcz niemożliwe. Przypuszcza się, że w czasach, kiedy ludzie uczyli się rolnictwa, a następnie udomowili dziką winorośl, zrobili to, krzyżując kolejno dzikie i udomowione szczepy (Zohary 1996, s. 24-25). Możliwe też, że współczesna mapa występowania winorośli sylvestris może przypominać rozmieszczenie pierwotnych dzikich odmian w ich naturalnych siedliskach, zdziczałych form 
udomowionych oraz hybryd pomiędzy dziką leśną winoroślą a udomowioną winną latoroślą (Renfrew 1996, s. 255).

Dobrym przykładem obszaru, na którym nadal występują liczne populacje dzikiej winorośli leśnej jest Grecja (od co najmniej plejstocenu). Obecnie zasięg jej występowania jest bardzo szeroki: szczególnie w północnej Tracji, wschodniej i zachodniej Macedonii, Epirze, Tesalii, Eubei i na Peloponezie - w lasach mieszanych, na aluwialnych i ubogich glebach, najlepiej na stosunkowo wilgotnych gruntach. Odmiany winorośli silvestris wspinających się na drzewa i obrastających je do wysokości $30 \mathrm{~m}$ lub wyżej ${ }^{1}$ mogą rosnąć na obszarach położonych do $400 \mathrm{~m}$ n.p.m., niekiedy $800 \mathrm{~m}$ n.p.m., przy temperaturze co najmniej $16^{\circ} \mathrm{C}$ w czasie najcieplejszych letnich miesięcy. Dzikie winogrona są dwupienne, a ich populacje zawierają mniej więcej $\mathrm{w}$ równych proporcjach formy męskie i żeńskie. Owoce powstają w wyniku zapylenia krzyżowego. Opisywane dzikie odmiany stanowią przeciwieństwo udomowionych, ponieważ formy, w których kwiaty zawierają zarówno słupki, jak i pylniki nie wymagają zapylenia krzyżowego (Renfrew 1996, s. 255, 257-258).

Obecnie w niektórych rejonach świata nadal uprawia się w ten sposób winorośl, np. w Vinho Verde w północnej Portugalii i w wielu górskich wioskach Azji Środkowej. Rośnie ona obok drzew. Należy ją często przycinać, aby umożliwić przejście pomiędzy roślinami oraz zmniejszając ich rozrastanie, zapewnić więcej owoców o lepszym smaku. Winogrona można zbierać bez konieczności wspinania się na drzewa. Należy jednak pamiętać o odpowiedniej i regularnej pielęgnacji, ponieważ bardzo szybko drzewa i winna latorośl zamieniają się w gąszcz (Olmo 1996, s. 38).

Obszar występowania dzikiej odmiany winorośli (Vitis vinifera L. ssp. silvestris) w Europie wyraźnie się zmniejszył, na co miały wpływ filoksera winiak (mszyca przywieziona z Ameryki Północnej w 1860 r.) oraz mączniak prawdziwy i rzekomy, również z Nowego Świata, które zniszczyły leśne siedliska (Arnold, Gillet, Gobat 1998, s. 159).

Analiza rozmieszczenia i rozprzestrzeniania się dzikich i uprawnych odmian Vitis vinifera L. umożliwiła odtworzenie przebiegu udomowienia winnej latorośli, opisanego w następujący sposób przez L. Levadoux:

1) Vitis vinifera $L$. występowała już pod koniec starszego okresu ery kenozoicznej (w neogenie) i na początku czwartorzędu, co potwierdzają znaleziska skamieniałości odkryte w wielu miejscach Europy Zachodniej i w basenie Morza Śródziemnego.

2) Na zalesionych obszarach wybrzeży Morza Śródziemnego i wzdłuż południowych brzegów Morza Kaspijskiego znaleziono paleobotaniczne pozosta-

\footnotetext{
${ }^{1}$ Występują w pobliżu drzew następujących gatunków: Cercis siliquastrum, Laurus nobilis, Arbutus unedo i Arbutus andrachne, Olea oleaster, Platanus orientalia, Quercus coccifera, Pistacia terebinthus, Clematis vitalba, Ulmus campestris, Cornus mas $i$ Cornus sanguinea, Corylus avellana, Rubus sp., Fagus silvatica, Pyrus amygdaliformis, Rosa sp. i Castanea sativa (Renfrew 1996, s. 255, 257).
} 
łości winorośli pochodzące z pleistocenu (pierwszej epoki czwartorzędu). Jej populacje rozwijały się samodzielnie w różnych kierunkach przez wiele setek tysięcy lat.

3) W epoce neolitu winorośl zajmowała prawie ten sam obszar co obecnie, choć o mniejszym zróżnicowaniu klimatycznym. Prymitywny polimorfizm i dwupienność lasów pozostała nienaruszona dzięki heterozygotyczności roślin.

4) Początki uprawy zboża na Bliskim Wschodzie datuje się na okres pomiędzy 9 a 6 tysiącleciem p.n.e., skąd ta gałąź rolnictwa rozprzestrzeniła się na inne obszary basenu Morza Śródziemnego i Europy.

5) Udomowienie winorośli na Zakaukaziu nastąpiło w $8-6$ tysiącleciu p.n.e.

6) Pod koniec 5 tysiąclecia p.n.e. uprawa winnej latorośli rozprzestrzeniła się nad Morzem Egejskim, w Mezopotamii, Syrii i w Egipcie.

7) $\mathrm{W}$ czasie pierwszego tysiąclecia p.n.e. rozpoczęto uprawę winorośli w środkowej i północnej części Włoch, Francji (Prowansji), Afryce Północnej i w Hiszpanii.

8) Badania odmian vinifera sylvestris przeprowadzone przez A.M. Negrula pozwoliły ustalić, że jedna z nich prawdopodobnie dominowała w regionie Morza Kaspijskiego, zaś na innych analizowanych obszarach: Europy, Anatolii i Afryki Północnej, na zachód od Kaukazu, odkryto jedynie jej niewielkie pozostałości. Odmiany te nie są jednorodne, podzielono je wg różnych ekotypów i zweryfikowano dzięki badaniom przeprowadzonym w dolinach Renu i Dunaju oraz w innych miejscach. Nie można wykluczyć, że doszło do hybrydyzacji między szczepami winorośli zajmującymi sąsiednie tereny. Łatwiej odtworzyć genezę ekotypów winogron występujących w bardziej umiarkowanych strefach Europy: Portugalii, Francji i Nadrenii (Olmo 1996, s. 36).

Bardzo ważną rzeczą, o której nie należy zapominać, jest to, że winorośl w stanie dzikim charakteryzowała się dużą ilością smacznych i pożywnych owoców, szczególnie we wschodniej części obszaru jej występowania. Większość dzikich odmian owoców, takich jak: figi, jabłka, gruszki, gorzkie migdały i twarde orzechy również była bardzo smaczna. Analiza paleobotanicznych znalezisk pestek winogron wykazała, że dzika winorośl występowała na bardzo dużym obszarze i stanowiła pożywienie ludzi zanim jeszcze zaczęli prowadzić osiadły tryb życia. Udomowienie winorośli nie było problemem odkąd zaczęto uprawiać zboże, a sezonowość wszelkich działań rolniczych, takich jak: orka, sianie ziarna, żniwa i pozyskiwanie nasion do zasiewów narzucało osiadły tryb życia (Olmo 1996, s. 38).

Ludzie udomowili winorośl, aby zwiększyć ilość owoców i udoskonalić ich smak. Pierwsze udomowione szczepy nadal krzyżowano z sadzonkami dzikiej winorośli, żeby doprowadzić do wykształcenia się najlepszych cech tych roślin (Olmo 1996, s. 37). Dobrym tego przykładem są badania pozostałości winnej latorośli znalezionej w rzymskich i galo-rzymskich winnicach w okolicach Narbony, które po- 
twierdziły różnorodność biologiczną analizowanych szczepów. Odkryte tam odmiany uprawne powstawały dzięki krzyżowaniu odmian dzikich z dzikimi lub uprawnych z dzikimi (Bouby, Terral, Figueiral, Ivorra, Lacombe, Pastor, Picq, Bouffat, Fabre, Jung, Marinval, Petitot, Tardy 2010, s. 137).

W miejscach, gdzie dzika winorośl stanowiła część rodzimej flory, winna latorośl zaczęła być wykorzystywana do produkcji wina. Założenie winnicy umożliwiały: obecność stałego źródła wody, aby dało się nawodnić pole oraz znalezienie sposobu na ochronienie jej przed wypasanymi zwierzętami, głównie kozami i owcami. Najlepsze warunki do spełnienia pierwszego wymogu panowały na dość dużych wysokościach, w dolinach górskich, w których płynęły strumienie (w lecie zasilane w wodę przez topniejące śniegi z bardzo wysokich pasm górskich). Na południowych stokach, na obszarach rozciągających się ze wschodu na zachód panowały jeszcze lepsze warunki ze względu na lasy chroniące winorośl przed napływem zimnych mas powietrza. Poszczególne szczepy dzikiej winorośli rosnące w lesie lub w nadbrzeżnych siedliskach wybierano do udomowienia na podstawie największej ilości owoców i regularności ich produkcji, aby myśliwi i zbieracze co roku zbierali owoce $\mathrm{z}$ tych samych krzewów. Możliwe, że powycinano rośliny, których nie udomowiono lub oznakowano te, które włączono do uprawy. Jeśli dzika winorośl intensywnie rozwijała się w jakiejś okolicy i rodziła dużo owoców, mogło dojść do zwiększenia nacisku na uzyskanie jak najsłodszych winogron.

Wraz z osiadłym trybem życia i wprowadzeniem gospodarki opartej na rolnictwie zachowano część dzikich drzew owocowych oraz krzewów dzikiej winorośli, pamiętając o tym, że nie można wykarczować całego lasu ze względu na produkty, które z niego pozyskiwano (drewno, owoce, zwierzynę łowną, skóry) oraz z powodu roli osłony, którą pełniły drzewa leśne dla otwartych pastwisk. Obszar zamieszkiwany przez ludzi otaczano murami zbudowanymi z cegieł z suszonego błota, kamieniami oznaczano granice lub wykorzystywano naturalne bariery, takie jak np. kolczaste zarośla, aby ochronić go przed intruzami - ludźmi i zwierzętami. Wzdłuż obrzeży pozostawiano drzewa, szczególnie przy małych strumieniach wody wykorzystywanej do nawadniania. $\mathrm{Z}$ czasem zaczęły powstawać pierwsze ogrody, ale ciągle wykorzystywano naturalną skłonność do symbiozy drzew leśnych i winorośli, dzięki czemu winogrona oplatały i opierały się na drzewach liściastych (Olmo 1996, s. 37).

Uprawna winna latorośl rozprzestrzeniła się od krawędzi lasów do suchych i gorących obszarów pustynnych, często bez wsparcia sąsiadujących z nią drzew, po prostu wyrastając ponad powierzchnią ziemi. Bez wystarczającej ilości opadów usychała, więc koniecznością stało się nawadnianie na najbardziej suchych glebach. Najlepszymi terenami do zakładania winnic stały się obszary o lekkim nachyleniu i dużej powierzchni. Jeśli produkcja wina przekraczała zapotrzebowanie lokalne, uprawa winorośli opierała się na kilku wyspecjalizowanych odmianach, z których każda była hodowana z myślą o wytwarzaniu określonego trunku na konkretny rynek przeznaczenia (Olmo 1996, s. 38). 
Wiemy, że rozprzestrzenianie się dzikiej winorośli miało często charakter przypadkowy, ale nie możemy zapominać, że w starożytności zarówno dla rozmnażania dzikiej, jak i udomowionej winnej latorośli stosowano odkłady, sadzonki lub szczepienia. Szczepienie pozwalało odmładzać winnice i zwiększać wydajność uprawy (Bouby i in. 2010, s. 135).

W źródłach historycznych pozostawionych przez autorów rzymskich można zauważyć świadomość wad dotycących metod rozmnażania winorośli (Columella ed. Hedberg 1968). Zalecają oni stosowanie rozmnażania wegetatywnego poprzez np. sadzonkowanie i szczepienie. Pochłaniają one więcej czasu niż rozmnażanie generatywne (z nasion), ale uzyskane szczepy winorośli posiadają wszystkie cechy roślin matecznych, co nie jest normą w przypadku tych wyhodowanych z nasion.

U arabskiego agronoma Ibn Al-Awwama z Andaluzji żyjącego w XII w. możemy znaleźć pozytywne opinie dotyczące wysiewu i stosowania nasion (Księga o rolnictwie, VII, s. 45-46). Według niego wszystkie ukorzenione rośliny oraz nasiona powinny być zasiane $\mathrm{w}$ odpowiednio przygotowanej glebie w okresie od marca do września. Badania genetyczne obecnie istniejących kultywarów winorośli wykazały, że powstały one w wyniku krzyżowania różnych gatunków przez człowieka lub samozapylenia (Olmo 1996, s. 136).

\section{OBECNIE UPRAWIANE GATUNKI WINOROŚLI}

Winogrona rodzaju Vitis dzielą się na trzy grupy: północnoamerykańską, euroazjatycką i azjatycką. Kryterium podziału stanowi położenie geograficzne. Botanicy wydzielili 25-30 gatunków amerykańskiego pochodzenia, tyle samo azjatyckiego i jeden gatunek euroazjatycki, który w największym stopniu wpłynął na rozwój upraw winnej latorośli na całym świecie i powstawanie kolejnych kultywarów. Większość opisywanych powyżej gatunków występuje w strefach klimatu umiarkowanego na półkuli północnej, najczęściej na terenach zalesionych, o stosunkowo wysokich opadach. Według F. Zhang ponad 80 współcześnie znanych gatunków winorośli pochodzi z Chin (Olmo 1996, s. 31). Ocenia się, że obecnie istnieje około 10 tys. kultywarów wywodzących się z dzikiego gatunku Vitis vinifera ssp. Sylvestris z Bliskiego Wschodu, które objął swoimi badaniami A.M. Negrul (Renfrew 1996, s. 258).

W 1946 r. A.M. Negrul zebrał i opisał wiele odmian winorośli właściwej Vitis vinifera L. występujących w Europie i Azji Środkowej. Skatalogował różne gatunki oraz przypisał je do konkretnych ekotypów, biorąc pod uwagę: obszar geograficzny, cechy morfologiczne i reakcje fizjologiczne, którym podlegają. Poniższe zestawienie odmian opracował L. Levadoux na podstawie pracy A.M. Negrula: 
1) Occidentalis - Francja, Niemcy, Hiszpania i Portugalia. Typowe odmiany winogron występujących w Europie Zachodniej, z małymi, zbitymi gronami, z włoskami pajęczynowymi, małymi białymi lub czarnymi jagodami, o średniej zawartości cukru i wysokiej kwasowości, winorośl bardzo wydajna w produkcji wina, szczep tolerujący niskie temperatury. Przykład: Pinot noir (czerwona odmiana winorośli) (a także: Riesling, Traminer, Aligoté, Gamay, Pinot, Chardonnay, Malingre précoce, Madeleine Angevine, Cabernet, Verdot, Sémillon, Sauvignon, Muscadelle, Folle blanche, Morrastel, Mourvèdre, Aléatico, Verdelho, Sercial, Oporto, Touriga, Albilho).

2) Orientalis - Azja Środkowa, Iran, Afganistan, Armenia i Azerbejdżan. Mało gron, gładkie, pozbawione włosków liście, jagody głównie pełne, duże i o wydłużonym kształcie, mięsisty miąższ, przeważnie białe, ale także często czerwone owoce, niska kwasowość, pestki średniej i dużej wielkości, „haczykowato” zakończone, część winogron bez pestek, winorośl mało odporna na zimno, długi okres wegetacji. Przykład: bezpestkowe wino Thompson (Sultana) (a także: Muscat blanc à petits grains, Muscat d'Alexandrie, Cinsaut, Ohanes, Cornichon, Sultanine, Khalili, Charas, Katta-Kurgan, Rich Baba).

3) Pontica - Azja Mniejsza, Grecja, Węgry, Rumunia, Gruzja, Besarabia. Średniej wielkości zbite grona $\mathrm{z}$ różnymi rodzajami włosków, pajęczymi i filcowanymi na dolnej powierzchni, jagody zwykle okrągłe, średniej wielkości, soczyste, białe, czerwone i czarne, podobnie wyglądające, z pestkami wielkości od małej do bardzo dużej, duża część winogron bez pestek. Winorośl o dużej wydajności produkcyjnej, bardzo znany typ winogron o średniej zawartości cukru i wysokiej kwasowości. Rozmnaża się poprzez samozapylenie, co często prowadzi do wykształcenia się roślin skarlałych i o dziwnych typach liści. Przykład: Saperavi (a także: Furmint, Hars Levelu, Vermentino, Clairette, Corinthe, Mtsvanie, Rka-Tsiteli, Saperavi, Alvarna, Kakur, Plavai, Chaouch, Dodrelabi) (Levadoux 1956, s. 96-97; Olmo 1996, s. 35).

L. Levadoux zauważył, że A.M. Negrul sporządził bardzo uproszczoną klasyfikację winorośli dla zachodniej części basenu Morza Śródziemnego. Pominął w niej liczne odmiany winnej latorośli występujące we Włoszech, Hiszpanii i Afryce Północnej, a do swoich badań włączył tylko kilka z nich (Levadoux 1956, s. 97-98).

Klasyfikacja A.M. Negrula obejmuje trzy grupy winorośli. Niektóre z wymienionych w nich gatunków uprawia się na bardzo dużych obszarach, choć trudno dokładnie określić granice ich występowania, tak jak odtworzyć zmiany ewolucyjne, którym podlegała winna latorośl od starożytności do czasów współczesnych. W przypadku wielu odmian dochodziło do hybrydyzacji lub przenoszenia się na inne tereny. Trzeba także wspomnieć o powstaniu islamu oraz o edyktach władców i urzędników uwarunkowanych zasadami tej religii, które wpłynęły na zmiany w uprawie konkretnych odmian winorośli na wielu obszarach. Przewagę gatunków winogron wykorzystywanych do produkcji win stołowych w grupie orientalis można thumaczyć zakazem produkcji alkoholu zawartym w koranie (Olmo 1996, s. 37). 


\section{DZIKA A UDOMOWIONA WINOROŚL}

H.P. Olmo porównał cechy morfologiczne współcześnie występujących gatunków dzikiej i udomowionej winorośli i zestawił je w formie tabeli (Olmo 1996, s. 33).

\begin{tabular}{|c|c|c|}
\hline & $\begin{array}{c}\text { Dzika winorośl } \\
\text { (vinifera sylvestris) }\end{array}$ & $\begin{array}{c}\text { Udomowiona winorośl } \\
\text { (vinifera sativa) }\end{array}$ \\
\hline $\begin{array}{l}\text { Pień (wieloletnie } \\
\text { ramię) }\end{array}$ & $\begin{array}{l}\text { Często rozgałęziony, smukły, kora od- } \\
\text { dziela się bardzo długimi, cienkimi } \\
\text { paskami, mniej liściasty. }\end{array}$ & $\begin{array}{l}\text { Gruba kora oddziela się szerszymi } \\
\text { i bardziej spoistymi paskami. }\end{array}$ \\
\hline $\begin{array}{l}\text { Łozy (pędy, które } \\
\text { osiągnęły rok) }\end{array}$ & $\begin{array}{l}\text { Smukłe, długie międzywęźla, elastyczne, } \\
\text { twarde drewno, okrągłe w przekroju, } \\
\text { wici przypominające drut i silnie poskrę- } \\
\text { cane, uśpione pąki z małym spiczastym } \\
\text { wierzchołkiem, łuski pąków zimowych } \\
\text { szczelnie zamknięte. }\end{array}$ & $\begin{array}{l}\text { Duża średnica, krótsze międzywęźla, } \\
\text { w przekroju o kształcie elipsy, wici } \\
\text { większe i bardziej rozbudowane, } \\
\text { bardziej poskręcane przy końcówkach, } \\
\text { uśpione pąki duże i bardziej wystające, } \\
\text { ze spłaszczonym wierzchołkiem, łuski } \\
\text { pąków zimowych luźno zamknięte. }\end{array}$ \\
\hline Liście & $\begin{array}{l}\text { Małe, zwykle mocno zaokrąglone i trzy- } \\
\text { klapowe, ogonki krótkie i smukłe, o ma- } \\
\text { towej powierzchni, zagłębienie liścia } \\
\text { przy nasadzie ogonka szerokie i otwarte. }\end{array}$ & $\begin{array}{l}\text { Duże, wiele z nich z płytkimi zagłę- } \\
\text { bieniami także na całej powierzchni, } \\
\text { grube ogonki, gładko-faliste, wiele } \\
\text { z błyszczącą powierzchnią, zagłębie- } \\
\text { nie liścia przy nasadzie ogonka czę- } \\
\text { ściowo zamknięte. }\end{array}$ \\
\hline Kwiatostan & $\begin{array}{l}\text { Winorośl rozdzielnopłciowa, rzadziej } \\
\left.\text { obupłciowa. Męskie osobniki ( }{ }^{\lambda}\right) \text { mają } \\
\text { płodny pyłek, ale nieowocujący. Żeńskie } \\
\text { osobniki (q) mają bezpłodny pyłek i aby } \\
\text { doszło do owocowania konieczne jest } \\
\text { zapylenie krzyżowe. W wyjątkowych przy- } \\
\text { padkach zdarza się zmiana płci u mę- } \\
\text { skich osobników }(\hat{\partial} \rightarrow+\text { ) } \text { u których } \\
\text { dochodzi do wykształcenia się żeńskich } \\
\text { organów rozrodczych i funkcjonują one } \\
\text { jako organizmy obupłciowe. }\end{array}$ & $\begin{array}{l}\text { Winorośl zwykle obupłciowa, bardzo } \\
\text { nieliczne osobniki są płci żeńskiej (ㅇ). } \\
\text { Samozapylenie jest regułą u obojnia- } \\
\text { ków. }\end{array}$ \\
\hline Klastry owoców & $\begin{array}{l}\text { Mały, od kulistego do stożkowatego } \\
\text { kształtu, luźne, nieregularne rozmiesz- } \\
\text { czenie, zmienna dojrzałość jagód } \\
\text { w klastrze, ogonek bardzo długi i smu- } \\
\text { kły. }\end{array}$ & $\begin{array}{l}\text { Duży, wydłużony, zwarty, ścisłe } \\
\text { rozmieszczenie, jagody dojrzewające } \\
\text { w tym samym czasie, mocno osadzo- } \\
\text { ny, gruby i sztywny ogonek. }\end{array}$ \\
\hline Jagody & $\begin{array}{l}\text { Małe, okrągłe lub spłaszczone, o niezbyt } \\
\text { wydłużonym kształcie, koloru czarnego, } \\
\text { rzadziej białego, o odpornej skórce, duże } \\
\text { nasycenie barwy, wytrzymałość, duża } \\
\text { ilość pestek, wodnisty sok, duża kwa- } \\
\text { skowatość, mała zawartość cukru. }\end{array}$ & $\begin{array}{l}\text { Duże, o kształcie od owalnego do } \\
\text { elipsowatego, o szerokiej gamie kolo- } \\
\text { rów, z mniejszą zawartością barwnika, } \\
\text { mało nasion o zmiennej liczbie, } \\
\text { umiarkowana kwaskowatość i zawar- } \\
\text { tość cukru. }\end{array}$ \\
\hline Pestki & $\begin{array}{l}\text { Małe, o okrągłym kształcie, wysoki } \\
\text { stosunek szerokości do długości }(>0,70) \text {, } \\
\text { bardzo opłacalne, krótki dziobek. }\end{array}$ & $\begin{array}{l}\text { Duże, o gruszkowatym kształcie, } \\
\text { niższy stosunek szerokości do długości } \\
(<0,60) \text {, niska rentowność, długi } \\
\text { dziobek, bardzo zmienne w wielkości } \\
\text { i kształcie. }\end{array}$ \\
\hline
\end{tabular}


Dzikie odmiany winorośli różnią się od uprawnych heterozygotycznością (winna latorośl w winnicach jest najczęściej homozygotyczna i ulega samozapyleniu) oraz cechami morfologicznymi: jagody i grona uprawnych winorośli są większe od dzikich, liście zakończone szypułkami, a nasiona o bardziej wydłużonym kształcie i ze spiczastym dziobkiem. Najstarsze odmiany udomowionej winnej latorośli mają najwięcej cech zbliżonych do dzikich gatunków winorośli. Przejawia się to w wielkości i kształcie nasion podobnych do tych u $V$. vinifera sylvestris oraz małej wielkości owoców o kulistym kształcie, zebranych w niewielkie grona, a także w kiełkowaniu opisywanych roślin na duże wysokości. Kultywary, chociaż charakteryzują się większymi nasionami, mają mniejszą wytrzymałość, produkują owoce o znacznie większej miąższości oraz większych i bardziej zróżnicowanych kształtach jagód (Bouby, Marinval 2001, s. 16).

Podstawowymi kryteriami sformułowanymi przez L. Levadoux i stosowanymi do rozróżnienia pestek dzikiej i udomowionej winorośli stały się ich kształt i wielkość. Można założyć, że pestki dzikich winogron są najczęściej małej wielkości, okrągłego, sercowatego kształtu, zakończone spiczastym, krótkim dziobkiem. W przypadku udomowionej winnej latorośli mamy do czynienia z większym zróżnicowaniem, ale można uogólnić opis do takich cech, jak: duża wielkość, owalny kształt i długi, spiczasty dziobek.

Przez bardzo długi czas archeobotanicy stosowali kryteria morfologiczne w analizie znalezisk. Podstawową pracą w tej dziedzinie stała się publikacja wyników badań przeprowadzonych przez A. Stummera w 1911 r. na świeżych pestkach winogron z różnych kultywarów i dzikich populacji z obszaru Austrii. Opracował on indeks biometryczny, który na podstawie stosunku długości i wielkości pestek pozwalał na przyporządkowanie ich do form dzikich lub uprawnych. Wskaźniki te wynosiły dla uprawnej winorośli: $0,44-0,53$, a dla dzikiej: $0,76-0,83$. Pomimo dużego sukcesu archeobotanicznego, jakim okazały się badania A. Stummera (wskaźnik Stummera), jego ustalenia miały wady. Nie wszystkie pestki można jednoznacznie zaliczyć do jednej z tych dwóch grup. Duży wpływ na wygląd pestek ma karbonizacja, która wyraźnie je deformuje. Należy o tym pamiętać szczególnie w przypadku zwęglonych pestek lub nasion najczęściej znajdowanych na terenach wyżynnych lub górskich. H. Smith i G. Jones w pracy z 1990 r. zwrócili uwagę na to, że wysuszenie i karbonizacja wpływa na zwiększenie wartości indeksu Stummera. Jeśli doszło do zwęglenia (karbonizacji) w bardzo wysokiej temperaturze, np. $450^{\circ} \mathrm{C}$, dochodzi do zniekształcenia pestek i po pomiarze pozostałości winorośli uprawnej mają taki sam indeks jak V. sylvestris (Bouby, Marinval 2001, s. 16-17).

Od czasów badań A. Stummera (Stummer 1911, s. 283-296) powstawało dużo prac, w których pomiary i indeksy opierały się na kryteriach, takich jak: wygląd pestki, dziobka, chalazy i zagłębień (Kislev 1988, s. 236-242; DiVora, Castelletti 1995, s. 333-358; Mangafa, Kotsakis 1996, s. 409-418). Szczególnie interesujące wyniki przyniosły badania M. Magafy i K. Kotsakisa, którzy przebadali nie tylko 
paleobotaniczne pozostałości winorośli, ale także obecnie występujące w Grecji gatunki dzikiej i uprawnej winnej latorośli i zaproponowali cztery formuły pozwalające wyróżnić dwa podgatunki spośród objętego badaniami materiału. Na podstawie 10 pomiarów i 12 cech zgodności autorzy wybrali miary i wskaźniki najbardziej charakterystyczne, pomijając najtrudniejsze do określenia i niepewne oraz najbardziej uszkodzone w wyniku zwęglenia (karbonizacji) pestki. Podkreślili, że stworzone przez nich formuły nie są stosowane w przypadku jednostek zwęglonych, umieszczonych $\mathrm{w}$ przedziałach zmniejszonej zmienności, przypisanych $\mathrm{z}$ pewnym prawdopodobieństwem do jednego lub drugiego podgatunku. Pozytywną stroną opisywanej metody jest konieczność wykonywania tylko trzech pomiarów (długości pestki, długości ogonka, pozycji chalazy) i wynikających z nich zgodności. Niewielką wadę stanowi pominięcie kilku odmian i populacji dzikiej winorośli występujących w Grecji, co do których nie można stosować formuł ustalonych przez M. Mangafę i K. Kotsakisa. Ważną rzeczą, o której należy pamiętać przed podjęciem badań nad archeobotanicznymi pozostałościami winnej latorośli w różnych krajach, jest potrzeba dokładnej analizy dzikich i uprawnych odmian winorośli występujących współcześnie na badanym obszarze i mających to samo miejsce pochodzenia co paleobotaniczny materiał (Bouby, Marinval 2001, s. 17).

\section{CELE I MOŻLIWOŚCI BADAŃ ARCHEOBOTANICZNYCH}

Archeolodzy i paleobotanicy zajmują się badaniami pozostałości winnej latorośli, aby uzyskać jak najwięcej informacji dotyczących jej udomowienia, odtworzenia obszarów występowania dzikiej i udomowionej winorośli, odróżnienia obu odmian oraz ustalenia metod uprawy winnej latorośli i technologii produkcji wina.

Warunkiem przeprowadzenia analizy szczątków paleobotanicznych jest dobry stan zachowania: pestek, łodyg, skórek winogron, całych owoców i liści (Renfrew 1996, s. 265). Najlepsze rezultaty przynoszą badania archeobotaniczne: pyłków, zdrewniałych części winorośli (bardzo dobrze, jeśli w formie zwęglonej) i pestek. W przypadku pyłków i zdrewniałych części roślin nie da się przeprowadzić analizy paleobotanicznej według kryterium morfologicznego, pozostaje jedynie diagnostyka przy pomocy mikroskopu elektronicznego. W warstwach archeologicznych najczęściej odkrywa się pestki winogron, które przetrwały dzięki karbonizacji, imbibicji lub mineralizacji (Bouby, Marinval 2001, s. 16). Każda z części rośliny ma swoje charakterystyczne właściwości degradacji. Zachowany materiał archeobotaniczny pochodzący z tego samego stanowiska często różni się stanem dojrzałości botanicznej, na co mają także wpływ przypadkowe czynniki (Renfrew 1996, s. 266).

Badania archeologiczne prowadzone poza Mezopotamią dostarczyły bardziej wiarygodnych dowodów wczesnego udomowienia winnej latorośli niż analiza znalezisk pochodzących z dorzecza Tygrysu i Eufratu. Szczątki roślinne odkryte na 
obszarze Mezopotamii z konieczności interpretuje się dwuznacznie. Rozróżnienie pozostałości dzikiej i udomowionej winorośli opiera się na porównaniu stosunku szerokości do długości znalezionych pestek lub nasion. Nie zawsze dysponujemy na tyle licznym materiałem paleobotanicznym, żebyśmy mogli uzyskać wiarygodne wnioski. Dobrym przykładem tego typu problemów są 4 pestki winogron datowane na 700 r. p.n.e. i odkryte na stanowisku Tell Aswad w okolicach Damaszku, w Syrii. Trudno stwierdzić, czy należały one do dzikiej, czy udomowionej winorośli. Osąd pozostaje bardziej kwestią wiary niż nauki, ponieważ znaleziono i przeanalizowano zbyt małą ilość pestek (Powell 1996, s. 100). Trzeba również pamiętać o różnicach morfologicznych dostrzegalnych pomiędzy nasionami dzikich i udomowionych odmian Vitis vinifera występujących w Europie i nieprzydatnych przy badaniach archeologicznych jej bliskowschodnich odpowiedników (Zettler, Miller 1996, s. 125).

Całkowitą pewność co do przynależności do dzikiej lub uprawnej winorośli badanych szczątków organicznych możemy mieć tylko w przypadku analizy ampelograficznej, doskonale sprawdzającej się w badaniach współczesnych krzewów winogronowych i dotyczącej wyglądu różnych części rośliny, jej cech morfologicznych często zmieniających się w zależności od pory roku. Oczywiście archeobotanika ma mniejsze możliwości badawcze niż ampelografia ze względu na kontekst archeologiczny znalezisk, warunki, które panowały w miejscu odkrycia i stopień zachowania pozostałości paleobotanicznych. W praktyce badania archeobotaniczne ograniczają się do analizy pestek, pyłków i łodyg (zdrewniałych części winogronowych krzewów), a ampelograficzne - do liści, gron i pojedynczych jagód (Bouby, Marinval, 2001, s. 14).

Szczególnie ważnym źródłem informacji dla archeologów i paleobotaników jest węgiel drzewny. Oczywiście nie można stwierdzić, czy znalezione fragmenty drewna pochodzą z dzikiej, czy z uprawnej winorośli, ale mało prawdopodobne, żeby zbierano z nich drwa na opał (Zettler, Miller 1996, s. 125) (chociaż coroczne przycinanie winorośli przez ludzi mogło dostarczać chrustu do tego celu) (Zettler, Miller 1996, s. 126). Krzewy winnej latorośli nie tworzyły gęstych drzewostanów, a jej zdrewniałe pędy i łodygi nie są kruche i niełatwo je złamać (Zettler, Miller 1996, s. 125). W przypadkach pojawienia się trudności z jednoznacznym rozróżnieniem pestek dzikiej winorośli od uprawnej dużą pomocą okazuje się obecność pozostałości węgla drzewnego na tym samym stanowisku. Potwierdza to uprawianie winnej latorośli, szczególnie prawdopodobne na obszarach, na których nie zidentyfikowano dzikich odmian winorośli na innych stanowiskach archeologicznych (Zettler, Miller 1996, s. 126).

Dziedziną pomocną w prowadzeniu badań archeobotanicznych jest palinologia, ale analiza pyłków winorośli bywa ryzykowna ze względu na sposób ich rozprzestrzeniania się (Bouby, Marinval 2001, s. 17). Dobrym tego przykładem są kilkakrotnie podejmowane badania palinologiczne $\mathrm{w}$ rejonach słynących $\mathrm{z}$ uprawy winnej latorośli, które udowodniły niską zawartość pyłków winorośli w atmosferze, czego 
przykładem jest rejon Montpellier w basenie Loary i obszary położone w środkowych Włoszech (Bouby, Marinval 2001, s. 18).

Wiarygodne odtworzenie obrazu uprawy winorośli na określonym obszarze wymaga przebadania jak największej ilości znalezisk archeologicznych i archeobotanicznych, aby umożliwić porównanie uzyskanych danych i wykluczyć przypadkowe wnioski. Pojedyncze odkrycia pozostałości winnej latorośli mogą stanowić wystarczającą podstawę do analizy, ale tylko w tych rejonach, gdzie uprawa winorośli nie była planowa, a raczej spontaniczna i prowadzona z zamiarem zaspokajania potrzeb niewielkiej grupy ludzi. Oczywiście odkrycie pestek uprawnej winorośli na jakimś stanowisku archeologicznym nie musi oznaczać istnienia winnic w tym rejonie, ale znalezienie ich w większej ilości, przynajmniej w kilku miejscach na objętym badaniami obszarze oraz w różnych kontekstach archeologicznych, stanowi ku temu bardzo wyraźną przesłankę. Jeżeli odkryciom pestek winogronowych towarzyszą znaleziska innych części winorośli (tych zdrewniałych lub pyłków), a także pozostałości urządzeń do wyrobu wina, takich jak: tłocznie na wino, prasy, narzędzia do przycinania, resztki klastrów lub wytłoczyny po owocach winogron, możemy mówić o istnieniu lokalnej produkcji wina (Bouby, Marinval 2001, s. 17).

Trzeba również wspomnieć o rodzynkach, często wytwarzanych przy okazji wyrobu wina. W okresie starożytności, w pierwszym tysiącleciu p.n.e., była to dość ważna część handlu w basenie Morza Śródziemnego. Wiemy, że Rzymianie spożywali i konserwowali je na różne sposoby. Rodzynki można znaleźć przemieszane z innymi resztkami żywności zalegającymi w warstwach archeologicznych (Bouby, Marinval 2001, s. 17).

\section{NAJSTARSZE ZNALEZISKA ARCHEOBOTANICZNE DZIKIEJ I UPRAWNEJ WINOROŚLI}

Zanim ludzie udomowili winną latorośl, wykorzystywali jako pożywienie owoce dzikich winogron i prawdopodobnie z czasem nauczyli się z nich wytwarzać niewielkie ilości wina na potrzeby domowe. Naturalną konsekwencją udomowienia dzikiej winorośli i zakładania winnic stała się produkcja wina na mniejszą i większą skalę. Tak jak w przeszłości, obecnie wciąż występują dzikie i uprawne odmiany winorośli, często zajmując sąsiadujące ze sobą obszary. Czasami wytwarza się także wino $\mathrm{z}$ dzikich winogron, choć raczej na potrzeby lokalnych rynków zbytu².

Często zdarza się, że na stanowisku, na którym odkrywa się pozostałości świadczące o wyrobie wina z winorośli uprawnej, znajduje się również szczątki dzikiej

\footnotetext{
${ }^{2}$ Więcej informacji o uprawie winorośli patrz literatura przedmiotu: Jackson 2008; McGovern 2003; Orru, Grillo, Lovicu, Venora, Bacchetta 2008; Unwin 1996.
} 
winorośli. Najprostszym wytłumaczeniem jest chęć wykorzystania wszelkich dostępnych na miejscu owoców do produkcji wina. W dzisiejszych czasach nadal koegzystują populacje dzikich i uprawnych odmian winorośli, czego przykładem są północne Włochy i dzika winorośl o białych lub czarnych owocach oplatająca drzewa lub krzewy oddzielające poszczególne ziemie rolników. W okolicach Corte i Sartène na Korsyce jeszcze od końca XVIII w. do początku XX w. produkowano wino $\mathrm{z}$ winogron pozyskiwanych wyłącznie $\mathrm{z}$ dzikiej winnej latorośli. Morfotyp dzikiej winorośli zidentyfikowano obok uprawnego: nasiąknięte wodą pestki w Marsylii, Tulonie i Bordeaux oraz zwęglone pestki w Rians i Ambrussum (Bouby i in. 2010, s. 133-134).

\section{Archeobotaniczne znaleziska dzikiej winorośli}

Dzika winorośl (Vitis vinifera ssp. sylvestris) rozprzestrzeniła się na olbrzymim obszarze rozciągającym się od Portugalii do Turkmenistanu i od brzegów Renu do północnych lasów w Tunezji, nie omijając wielu miejsc w Anatolii. Najstarsze pestki dzikich winogron w Turcji zostały odkryte w Nevali Çori, blisko Urfy, w dolinie Eufratu i wydatowane na 8400 r. p.n.e. Analiza różnorodnych chlorotypów zawartych w chloroplastach populacji dzikiej winorośli obecnie występujących w środkowej i wschodniej części basenu Morza Śródziemnego wykazała większe zróżnicowanie niż w populacjach w zachodniej części opisywanego obszaru. Potwierdza to sugestię A.M. Negrula o umiejscowieniu początków istnienia dzikiej winorośli w Anatolii i na Kaukazie Południowym, na co wskazywałyby zmiany zaobserwowane w fenotypie tej rośliny (Gōkbayrak, Söylemezoglu 2010, s. 466).

Na wielu neolitycznych stanowiskach w Europie i na Bliskim Wschodzie odkryto zwęglone pestki winogron. Granice zasięgu rozmieszczenia tych znalezisk pokrywają się z terenami, na których obecnie występują dzikie winogrona sylvestris. Pod względem morfologicznym znalezione pestki przypominają dzikie formy (Zohary 1996, s. 27). Część nasion odkrytych na neolitycznym stanowisku Tell Abu Hureyra w Syrii przypuszczalnie pochodzi od dzikiej winorośli rosnącej wzdłuż górnego Eufratu (Zettler, Miller 1996, s. 126).

Innymi przykładami mogą być zwęglone pestki winogron znalezione nad górnym Eufratem, w południowo-wschodniej Turcji i północnej Syrii, na obszarze naturalnego występowania dzikiej winorośli, na stanowiskach: Korucutepe i Tepecik, Arslan Tepe, Kurban Höyük, Tell es-Sweyhat, Tell Hadidi i Tell Selenkahiyeh. Ślady Vitis vinifera odkryto także w naczyniu z Hama w środkowej Syrii. Kilka zwęglonych pestek winogron znaleziono w Hammam et-Turkmen nad rzeką Balikh w Syrii, w Tell Leilan nad rzeką Khabur (jej górnym biegu) i w Tell Taya w północnym Iraku (Zettler, Miller 1996, s. 126). 
Obecnie za najwcześniejszy ślad produkcji wina uważa się naczynie ceramiczne, w którym zidentyfikowano pozostałości kwasu winnego, datowane na koniec 6 tysiąclecia p.n.e., odkryte na stanowisku irańskim Hajji Firuz Tepe, na północ od gór Zagros. Nie można wykluczyć, że opisywany pojemnik ceramiczny wypełniało wino zrobione $\mathrm{z}$ winogron pochodzących $\mathrm{z}$ dzikiej winorośli (Bouby, Marinval, 2001, s. 18).

Najstarsze pozostałości dzikiej winorośli odkryte w Europie pochodzą z Grecji. $\mathrm{Na}$ wielu stanowiskach archeologicznych znaleziono paleobotaniczne szczątki dzikiej winnej latorośli datowane od paleolitu do epoki żelaza. Bardzo często na tych samych obszarach odkrywano pestki dzikiej i uprawnej winorośli ${ }^{3}$. Pierwsze ślady występowania dzikiej winnej latorośli na Półwyspie Iberyjskim datuje się na neolit na 3 tysiąclecie p.n.e. (Arnold, Gillet, Gobat 1998, s. 163; Nuñez-Rivera, Walker 1989, s. 205-237; Walker, 1985, s. 163-182), a w południowej Francji prawdopodobnie na połowę mezolitu (Bouby i in. 2010, s. 130). Analiza najstarszych pozostałości archeobotanicznych odkrytych w Langwedocji wykazała, że odmiana ta występuje na tym obszarze do dzisiaj (Bouby i in. 2010, s. 135). Badania paleobotaniczne i archeologiczne pozwoliły ustalić, że choć w epoce żelaza zaczęto uprawiać winorośl i produkować wino na południu Francji, nadal występowały tam jednocześnie dzika i uprawna winorośl (Bouby i in. 2010, s. 130). Dzikie odmiany winnej latorośli mogły rosnąć także poza obszarem basenu Morza Śródziemnego, o czym świadczą znaleziska archeologiczne w Szwajcarii, odkryte w osadach jezior-

\footnotetext{
${ }^{3}$ Paleobotaniczne znaleziska winogron odkryto na stanowiskach archeologicznych w Grecji: w jaskini Franchthi w Argolidzie (z paleolitulmezolitu), w Argissie, Achilleion i Sesklo w Tesalii (z wczesnego neolitu), w Sitagroi we wschodniej Macedonii i Sesklo w Tesalii (ze środkowego neolitu), w Arapi, Dimini, Sesklo i Pefkakii w Tesalii, Dimitrze, Dikili Tash i Sitagroi we wschodniej Macedonii, Franchthi w Argolidzie (z późnego neolitu), w Argissie w Tesalii, Chalandriani na Syros (zawiera świadectwa liści winorośli), w Myrtos (zawiera świadectwa liści winogron) i Phaistos na Krecie, Kastanas w zachodniej Macedonii, w Synoro (zawiera świadectwa liści winogron), w Tirynsie i Lernie w Argolidzie, Markiani na Amorgos (zawiera świadectwa liści winorośli), w Sitagroi we wschodniej Macedonii i Aghios Kosmas w Attyce (z wczesnej epoki brązu), w Arapi, Dimini, Sesklo i Pefkakii w Tesalii, w Dimitrze, Dikili Tash i Sitagori we wschodniej Macedonii i we Franchthi w Argolidzie (z późnego neolitu), w Argissie w Tesalii, Chalandriani na Syros (zawiera świadectwa liści winorośli), w Myrtos (zawiera świadectwa liści winogron) i Phaistos na Krecie, Kastanas w zachodniej Macedonii, Synoro (zawiera świadectwa liści winogron) i w Lernie i Tirynsie w Argolidzie, Markiani na Amorgos (zawiera świadectwa liści winorośli), Sitagroi we wschodniej Macedonii i Aghios Kosmas w Attyce (z wczesnej epoki brązu), w Argissie i w Pefkakii w Tesalii, Assiros w zachodniej Macedonii, Atenach w Attyce, Knossos na Krecie, Lernie w Argolidzie, Nichorii w Messenii i Orchomenos w Beocji (ze środkowej epoki brązu), w Assiros i Kastanas w zachodniej Macedonii, w Dimitrze we wschodniej Macedonii, w Iolkos w Tesalii, Kato Zachro i Knossos na Krecie, Mycenae i Tirynsie w Argolidzie oraz Menelaion w Sparcie (zawiera świadectwa liści winorośli) (z późnej epoki brązu), w Assiros i Kastanas w zachodniej Macedonii, Atenach w Attyce, Demetrias w Tesalii i Samos we wschodniej Egei (z epoki żelaza) (Renfrew 1996, s. 266-267).
} 
nych jezior Neuchâtel i Léman, które wyraźnie potwierdzają występowanie dzikiej winorośli na brzegach zbiorników wodnych w epoce brązu (Arnold, Gillet, Gobat 1998, s. 162; Desfayes 1989, s. 161-165; Jacquat 1988).

\section{Archeobotaniczne znaleziska uprawnej winorośli}

Ponieważ nie wszystkie uzyskane próbki archeobotaniczne nadają się do analizy lub szczątki dzikiej i udomowionej winorośli występują w niewielkich ilościach, nasuwa się wniosek, że do upowszechnienia uprawy winnej latorośli doszło po raz pierwszy w 4 tysiącleciu p.n.e. Biorąc pod uwagę dużo liczniejsze ślady kontaktów kulturowych, widoczne w zespołach archeologicznych w okresie Uruk w drugiej połowie 4 tysiąclecia p.n.e., znajdujących się na obszarach rozciągających się łukowato przez Mezopotamię od południowo-zachodniego Iranu do Morza Śódziemnego, trudno dziwić się niewielkiej liczbie winnic występujących w tym okresie (Powell 1996, s. 101).

Amfora niewątpliwie lokalnego pochodzenia znaleziona na stanowisku Godin Tepe w Iranie z drugiej połowy 4 tysiąclecia p.n.e. została odkryta poza obszarem występowania dzikiej winorośli i prawdopodobnie zawierała wino wyprodukowane z uprawnej winnej latorośli (Bouby, Marinval 2001, s. 18). Chociaż wewnątrz naczynia znajdowały się organiczne ślady wina, $w$ tej samej warstwie nie znaleziono zwęglonych pestek winogron. Aż do 3 tysiąclecia p.n.e., wczesnej epoki brązu, pestki winogron nie występują regularnie wśród znalezisk archeologicznych. W połowie 3 tysiąclecia p.n.e. uprawa winnej latorośli rozciągnęła się daleko poza obszar naturalnego występowania dzikiej winorośli, o czym świadczą wyniki badań przeprowadzonych na stanowiskach: w Shahr-i Sokhte we wschodnim Iranie i Mehrgarh w Pakistanie (Zettler, Miller 1996, s. 126). Szczególnie wiele nasion winnej latorośli odkryto w Shahr-i Sokhte i określono ich chronologię na 3 tysiąclecie p.n.e. (Zohary 1996, s. 29). Również z epoki brązu pochodzą pozostałości winorośli znalezione na Zakaukaziu, w Gruzji i wydatowane na 3 tysiąclecie p.n.e. oraz wyraźnie liczniejsze na 2-1 tysiąclecie p.n.e. a także pochodzące z 2 tysiąclecia p.n.e. paleobotaniczne odkrycia z Armenii (Zohary 1996, s. 29).

D. Zohary zwrócił uwagę na to, że nie można traktować powyższych znalezisk jako wyraźną przesłankę potwierdzającą uprawianie winnej latorośli. Według niego najstarsze przekonujące świadectwa uprawy winorośli pochodzą $\mathrm{z}$ chalkolitu (ok. 3700-3200 r. p.n.e.) i wczesnej epoki brązu (około 3200-1900 r. p.n.e.) $\mathrm{z}$ Lewantu. Zwęglone pestki winogron wraz z pestkami oliwek odnaleziono w Tellesh-Shuna, na północy doliny Jordanu, i wydatowano na połowę 4 tysiąclecia p.n.e., a spalone jagody zawierające 2-3 pestki z wczesnego brązu, z 3200 r. p.n.e. w Jerycho. Listę najstarszych znalezisk uzupełniają szczątki winorośli z wczesnego brązu odkryte w Arad i Lackish w Izraelu oraz Numeira w Jordanii. Szczególnie dużo 
pozostałości winnej latorośli pochodzi z Numeiry. Położenie geograficzne w suchych rejonach poza obecnym zasięgiem występowania dzikiej winorośli wskazywałoby na to, że na południu Judei, w dolnej części doliny Jordanu i nad Morzem Martwym mogły być uprawiane winogrona w 4-3 tysiącleciu p.n.e., co świadczyłoby o obecności uprawnej winorośli w południowej części Lewantu od drugiej połowy 4 tysiąclecia p.n.e. (Jacquat, Martinoli 1999, s. 25-30; Zohary 1996, s. 28).

Umiejscowienie początków uprawy $V$. vinifera w północnym Lewancie wyraźnie potwierdzają wyniki badań z Kurban Höyük w Urfie, w południowej Turcji, gdzie znaleziono pestki winogron w warstwach datowanych na późny chalkolit, w których stanowiły 5\% uzyskanych próbek, 10\% - w warstwach ze starszych faz wczesnego brązu i $66 \%$ - w warstwach od połowy do późnej epoki wczesnego brązu. Jeden z wykopów wypełniały zwęglone nasiona winogron, szypułki i owoce. Prawdopodobnie odkrycie to obrazuje gwałtowny przebieg wzrostu uprawy winorośli w północnym Lewancie od końca 4 do połowy 3 tysiąclecia p.n.e. (Zohary 1996, s. 28).

Znaleziska paleobotaniczne ze stanowisk w Kurban Höyük (datowane na okres od późnego chalkolitu do wczesnego brązu), małe ilości węgla drzewnego z 3 tysiąclecia p.n.e. odkryte w południowo-wschodniej Turcji i w Malyan, na południu Iranu (w południowo-wschodniej części Mezopotamii), stanowią wiarygodny dowód na uprawianie winnej latorośli i wytłaczania soku z winogron. Znalezione szczątki organiczne składały się ze zwęglonych pestek, fragmentów owoców oraz szypułek. Przebadane próbki, choć zwęglone, nie zawierały właściwie węgla. Nie zidentyfikowano w nich nasion chwastów, których można było spodziewać się w nawozie, więc trudno mówić o użytkowaniu ich jako paliwa. Prawdopodobnie mogły to być pozostałości dwóch procesów produkcyjnych - wytłaczania soku z winogron na wino lub ocet i mielenia orzechów na olej lub jakiś posiłek.

Resztki moszczu winnego odkryte na stanowisku w Malyan (zwęglone i zmineralizowane pestki winogron z 3 tysiąclecia p.n.e.) można porównać ze znaleziskami z Banesh (3400-2600 r. p.n.e.) i Kaftari (2200-1650 r. p.n.e.) (kilka nasion winogron i niezwęglonych fragmentów winorośli z Banesh oraz ponad 100 zwęglonych pestek winogron $z$ Kaftari). Winogrona i winorośl przedstawiona na pieczęci cylindrycznej z Kaftari (mężczyzna siedzący na stołku i kobieta pod krzewem winorośli) potwierdzają, że produkowano tam wino. Malyan znajduje się daleko poza nowoczesną strefą dystrybucji dzikich winogron, więc znalezienie resztek moszczu winnego świadczyłoby o tym, że prawdopodobnie uprawiano tam winną latorośl (Zettler, Miller 1996, s. 126).

W południowej Mezopotamii, w przeciwieństwie do sąsiadujących z nią wokół terenów, nie odkryto paleobotanicznych pozostałości winorośli w na tyle dużych ilościach, żeby można było mówić o istnieniu winnic nastawionych na produkcję wina na dużą skalę na tym obszarze. Nie wiadomo, kiedy i dlaczego udomowiono winorośl na Bliskim Wschodzie, prawdopodobnie zaczęto ją uprawiać przed 3 ty- 
siącleciem p.n.e. na obszarach, gdzie naturalnie występowały dzikie winogrona, skąd rozprzestrzeniły się do innych części Bliskiego Wschodu (Zettler, Miller 1996, s. 125).

W młodszych fazach epoki brązu znaleziska botaniczne na Bliskim Wschodzie są częstsze i uzupełniane przez coraz większe ilości znajdowanych pras do tłoczenia winogron, naczyń do przechowywania wina i artystycznych przedstawień winogron i winorośli. O świeżych winogronach, rodzynkach i winie można znaleźć informacje na najstarszych tabliczkach klinowych z Mezopotamii od drugiej połowy 3 tysiąclecia p.n.e. (Zohary 1996, s. 28).

Badania archeologiczne prowadzone w Egipcie wykazały, że bardzo wcześnie zaczęto tam uprawiać winorośl. Pozostałości rodzynek, szczątki urządzeń i fragmenty naczyń używanych przy produkcji wina i do jego transportu odkrywane w dolinie Nilu datuje się na początek Starego Państwa. W grobowcach w Abydos i Nagadzie znaleziono pestki winogron z I Dynastii (około 2900 r. p.n.e.) oraz dużo pozostałości rodzynek z III Dynastii (około 2600 r. p.n.e.) w piramidzie Dżesera w Sakkarze. Zachowały się również hieroglificzne informacje o tłoczniach na wino (także na stanowiskach grobowych datowanych od czasów V Dynastii). W dolinie Nilu dotychczas nie odkryto żadnych szczątków dzikiej winorośli, co świadczyłoby o tym, że rozwój uprawy winnej latorośli, wytwarzania wina lub importu rodzynek i wina z Lewantu do Egiptu można umiejscowić we wczesnej epoce brązu (Zohary 1996, s. 28).

Najstarsze archeobotaniczne świadectwa udomowienia winorośli z obszaru Europy są późniejsze niż na Bliskim Wschodzie i pochodzą z Grecji lądowej i z Krety (Terral, Tabard, Bouby, Ivorra, Pastor, Figueiral, Picq, Chevance, Jung, Fabre, Tardy, Compan, Bacilieri, Lacombe, This 2010, s. 444), która stała się najważniejszym producentem wina w basenie Morza Śródziemnego w starożytności. Chociaż pestki winogron znalezione na stanowiskach archeologicznych w Tesalii i Macedonii datuje się na późny neolit (około 4300-2800 r. p.n.e.) (Zohary 1996, s. 28), to najwcześniejsze przekonujące świadectwa o istnieniu uprawy winnej latorośli pochodzą z wczesnego okresu helleńskiego IV (około 2200-2000 r. p.n.e.) ze stanowisk w Lernie (w południowej Grecji) i Sitagroi (w północnej Grecji). J.M. Renfrew przeanalizowała 32 nasiona odkryte w Sitagroi. Porównała pestki winogron z warstw datowanych na 4500-2000 r. p.n.e. z pestkami dzikiej winorośli wydatowanymi na okres: od środkowego neolitu do środkowej epoki brązu i stwierdziła, że uprawa winorośli w Macedonii mogła rozpocząć się na długo przed 2000 r. p.n.e. J.M. Hansen zauważył, że nie można brać za pewnik wyników jej badań ze względu na małą ilość przeanalizowanych próbek - 32 nasiona. Podobnie jak na stanowiskach bliskowschodnich, również na tych należących do kultury mykeńskiej i minojskiej odkrywano oprócz szczątków botanicznych: prasy do tłoczenia wina oraz naczynia do jego przechowywania i picia (Zohary 1996, s. 29). 
Eksploatacja dzikiej winorośli w Grecji rozpoczęła się w późnym paleolicie i była nadal kontynuowana po jej udomowieniu na krótko przed 6000 r. p.n.e., kiedy to winna latorośl stała się jedną z pierwszych uprawnych owocowych roślin. Poprzez przycinanie i szczepienie kontrolowano jej wzrost. Od końca neolitu zarówno dzika, jak i uprawna winorośl występowały razem na tych samych obszarach. Celem krzyżowania odmian dzikich i uprawnych było wykształcenie różnorodnych typów winnej latorośli przeznaczonych do różnych celów: do produkcji rodzynek i winogron deserowych oraz wielu rodzajów wina i octu (Renfrew 1996, s. 265).

Winiarstwo zyskiwało na znaczeniu, co potwierdziły badania archeologiczne we wczesnominojskim Myrtos i we wczesnohelladzkim Aghios Kosmas. Pomimo skromnych możliwości w zakresie uprawy winnej latorośli, wino, jako towar luksusowy, było dobrze przechowywane w glinianych amforach i mogło stanowić przedmiot handlu. Rozwój eksportu wina przyczynił się do wzrostu dobrobytu w Grecji i we wczesnych cywilizacjach egejskich z epoki brązu, o czym świadczą znaleziska egzotycznych naczyń do picia wykonanych ze szlachetnych materiałów (Renfrew 1996, s. 265).

Najstarsze wiarygodne świadectwa uprawy winorośli we Włoszech datuje się na drugą połowę pierwszego tysiąclecia p.n.e. Pochodzą one $\mathrm{z}$ cmentarzysk willanowiańskich z San Vitale, Castelbole i Bolonii z IX lub VIII w. p.n.e. oraz z Rzymu, z grobowców Cures Sabini z VIII-VII w. p.n.e. Nie ma wątpliwości, że w tym samym okresie, na południu Półwyspu Apenińskiego greccy koloniści uprawiali winną latorośl i produkowali wino, ale znaleziska archeobotaniczne na tych obszarach są jeszcze rzadkością (Zohary 1996, s. 29).

Greccy i feniccy koloniści stali się również prekursorami tej gałęzi rolnictwa w zachodniej części basenu Morza Śródziemnego. Dobrym tego przykładem są kraje Maghrebu, w których pod wpływem Fenicjan w pierwszej połowie pierwszego tysiąclecia p.n.e. rozwinęła się uprawa winnej latorośli (Terral, Tabard, Bouby, Ivorra, Pastor, Figueiral, Picq, Chevance, Jung, Fabre, Tardy, Compan, Bacilieri, Lacombe, This 2010, s. 444). Wraz z kształtowaniem się i rozwojem imperium rzymskiego szczepy winorośli dotarly także do umiarkowanych klimatycznie stref Europy w dolinie Renu (Zohary 1996, s. 29).

W przypadku południowej części Półwyspu Iberyjskiego przyjmuje się, że uprawa winnej latorośli $\mathrm{w}$ tym rejonie rozwinęła się dzięki Fenicjanom. Ich rola w powstaniu centrów produkcji wina jest bardzo prawdopodobna. Poświadczają to znaleziska archeologiczne np. na iberyjskim stanowisku l'Alt de Benimaquia (Denia, Alicante), zamieszkiwanym od początku VI w. p.n.e., na którym znaleziono 7000 pestek winogron. W północno-wschodniej Hiszpanii początki uprawy winnej latorośli i wytwarzania wina zawdzięczamy Fenicjanom, Kartagińczykom i greckim kolonistom z Ampurias. Potwierdza to analiza morfologiczna pestek datowanych na czasy późniejsze niż VI w. p.n.e. (Bouby, Marinval 2001, s. 18; Nuñez-Rivera, Walker 1989, s. 205-237). 
We Francji rozpoczęcie produkcji wina łączy się z datą założenia greckiej kolonii Massalii (Marsylii) przez Fokajczyków, skąd uprawa winorośli upowszechniła się w południowej Galii w V w. p.n.e., co obrazuje powstanie ważnych ośrodków komunikacji i handlu łączących wybrzeże Morza Śródziemnego z głębią lądu. Przykładem stanowiska pełniącego ważną rolę $\mathrm{w}$ tym procesie może być Lattes (Hérault). Po podbiciu Galii przez Rzymian najważniejszym regionem produkcji wina stała się obecna Langwedocja, a Gallia Narbonensis stała się najważniejszym eksporterem wina w Imperium Romanum pod koniec I i w II w. n.e. zarówno na rynek lokalny (na zachód i północ Galii), jak i do innych prowincji zachodniej części cesarstwa. Słynny edykt Domicjana z 92 r. n.e. o zniszczeniu winnic poza Italią, który wg starszych opracowań naukowych miał wspomóc rodzimą uprawę winorośli i produkcję wina na Półwyspie Apenińskim, a wg nowszych - zahamować szerzenie się zarazy niszczącej krzewy winogronowe - w Galii nie był wdrożony w życie. Cesarz Probus unieważnił rozporządzenie Domicjana w 300 r. n.e. Od IV w. wraz z przyjęciem chrześcijaństwa możemy mówić o rozprzestrzenieniu się uprawy winnej latorośli i upowszechnieniu kultury picia wina w całej Europie (Terral i in. 2010, s. 444).

\section{ŹRÓDLA HISTORYCZNE I ARCHEOLOGICZNE O UPOWSZECHNIENIU UPRAWY WINOROŚLI I KSZTALTOWANIU SIE KULTURY PICIA WINA NA BLISKIM WSCHODZIE}

Zarówno starsze, jak i nowsze badania archeologiczne oraz paleobotaniczne pozwoliły umiejscowić początki występowania dzikiej, a następnie uprawnej winorośli na obszarze Anatolii i Kaukazu Południowego (obecnej Gruzji, Azerbejdżanu i Armenii), skąd upowszechniły się w rejonie Żyznego Półksiężyca (rozciągającego się od Egiptu, przez Palestynę i Syrię do Mezopotamii), czyli w kolebce wielkich cywilizacji starożytnego Bliskiego Wschodu. Najstarsze informacje zawarte w źródłach historycznych i archeologicznych są zgodne i jako miejsce uprawiania winnej latorośli wskazują Mezopotamię. Sumerowie, Amoryci, Babilończycy, Chaldejczycy i Asyryjczycy pozostawili na tyle dużo pisemnych świadectw dotyczących wina i winogron, że choć w przybliżeniu jesteśmy w stanie określić pochodzenie dzikiej winorośli oraz ramy chronologiczne i geograficzne występowania uprawnej winnej latorośli i kształtowania się kultury picia wina.

Najstarszym źródłem pisanym potwierdzającym, że doszło do udomowienia winorośli są sumeryjskie tabliczki datowane na 4 tysiąclecie p.n.e. Trzeba jednak pamiętać, że uprawa winnej latorośli nie wiąże się z wprowadzeniem kultury picia wina, ponieważ Sumerowie i wszyscy ich następcy w południowej Mezopotamii 
mieli winnice, ale pili piwo, a wino było ciągle drogim i rzadkim trunkiem (Powell 1996, s. 121).

Wczesne wzmianki o uprawie winorośli i produkcji wina pochodzą z inskrypcji wykonanych w drugiej połowie 3 tysiąclecia p.n.e. w Mezopotamii i w Egipcie (Zohary 1996, s. 23). W 3 tysiącleciu p.n.e. po raz pierwszy pojawiają się przedstawienia wina u Sumerów, ale w 3-1 tysiącleciu p.n.e. stanowią jeszcze rzadkość (Powell 1996, s. 101).

Pierwsze pewne i w pełni wiarygodne świadectwa rozwinięcia się kultury picia wina pochodzą z około 1800 r. p.n.e. z północno-zachodniej Mezopotamii, w związku z Amorytami, którzy przynieśli z Syrii zwyczaj picia wina. W tym samym czasie za górami Taurus w Anatolii wykształciła się już w pełni kultura picia wina, co jednoznacznie poświadcza niewielka liczba znalezisk archeologicznych. Jak do tej pory, nie odkryto informacji zapisanych pismem klinowym i potwierdzających podobną sytuację na obszarze położonym na wschód od Tygrysu w okresie do 1 tysiąclecia. p.n.e. (Powell 1996, s. 121).

Za czasów imperium asyryjskiego można zaobserwować dobrze rozwiniętą kulturę picia wina nie tylko na terenie Syrii, ale także na ziemiach pogranicznych pomiędzy Turcją na północy a Syrią i Irakiem na południu. Wówczas po raz pierwszy w źródłach asyryjskich wymienia się wino w powiązaniu z Urartu (w późnej starożytności położona w jego granicach Armenia stanie się krajem słynącym z produkcji wina). Wino pojawiło się także na górzystych terenach pogranicza iracko-irańskiego (Powell 1996, s. 121).

Chociaż obszarem udomowienia winorośli i kształtowania się kultury picia wina stała się Mezopotamia, wprowadzanie uprawy winnej latorośli i produkcji wina w każdej z jej części i na graniczących z nią terenach Bliskiego Wschodu nie przebiegało tak samo. Można to zauważyć, porównując przebieg opisywanych procesów w Babilonii i Asyrii, a następnie w państwie nowobabilońskim założonym przez Chaldejczyków, które powstały na ziemiach wcześniej zajmowanych przez Sumerów i Akadów - ludy podbite przez Amorytów.

Zachowane źródła pisane z Babilonii prawie nie dostarczają dowodów na istnienie produkcji wina, chyba że wspominają o jego wysokiej cenie, natomiast zawierają dużo wzmianek o piwie. Nie oznacza to, że nigdy nie uprawiano winorośli, ale prawie całkowita nieobecność winogron i wina w ewidencji gospodarczej do 1 tysiąclecia p.n.e. wskazuje na to, jak rzadkim było ono towarem. Świadczyłoby to o rozwinięciu się kultury picia wina poza granicami Babilonii. Zależności między uprawą jęczmienia i produkcją piwa oraz winogron i wina można zaobserwować na obszarach położonych nad Eufratem, wokół obecnej granicy syryjsko-irackiej i nad Tygrysem wokół dzisiejszego miasta Tikrit. $\mathrm{W}$ granicach ziem położonych $\mathrm{w}$ górnych częściach dolin rzecznych i na nieco wyższych wysokościach, czyli tam gdzie dzięki opadom deszczu mogło rozwinąc się rolnictwo, wykształciła się uprawa winorośli i produkcji wina (Powell 1996, s. 101). 
Nawet dla najstarszego okresu, jakim były ostatnie lata przed 2000 r. p.n.e., kiedy imperium III dynastii z Ur (rządzącej zjednoczonym Sumerem i Akadem) kontrolowało większość ziem położonych w dorzeczu Tygrysa i Eufratu nie znaleziono jednoznacznych dowodów obecności wina w Babilonii - jego produkcji, składania go w daninach lub importu. Ogólny obraz, który wyłania się z tekstów zapisanych pismem klinowym pokazuje, że spożycie wina wzrastało z każdym stuleciem, ale aż do końca istnienia Babilonii picie wina było przywilejem głównie bogów i bogatych ludzi.

Wino nigdy nie stanowiło napoju zwykłych ludzi, o czym świadczą przechwałki Nabonida (555-539 p.n.e.) - ostatniego semickiego władcy babilońskiego aż do okresu islamskiego. Mówił on, że dzięki: „winu, doskonałemu «piwu» z gór (regionów górskich), z których mój kraj nie ma żadnego”, stał się tak bogaty, że „181 pojemników z winem zostało sprzedanych za jednego srebrnego szekla każde". Słowa Nabonida doskonale podsumowują kulturę picia wina w starożytnej Babilonii - wino po wysokiej cenie było dostępne dzięki importowi lub jako część daniny składanej przez ludność uzależnioną od Babilonii i zamieszkującą tereny poza nią (Powell 1996, s. 101).

Mieszkańcy starożytnego południowego Iraku zdecydowanie woleli pić piwo wytwarzane $\mathrm{z}$ jęczmienia, prawdopodobnie smakowało ono lepiej niż łatwo dostępne wina, a najlepsze piwa babilońskie kosztowały mniej niż tanie wina. Kulturę picia piwa w Babilonii można porównać do obyczajów panujących w tej materii w dzisiejszej Bawarii. W obecnych czasach, jeśli lubi się piwo, nie szuka się najlepszych gatunków tego napoju w krajach śródziemnomorskich. Ksenofont, który jako jeden $\mathrm{z}$ greckich najemników brał udział w walkach prowadzonych przez Cyrusa Młodszego (perskiego satrapę Lidii) z jego bratem Artakserksesem II (królem perskim) o tron perski w IV w. p.n.e., pisał o piwie pitym w sercu zachodniej Armenii, a nawet Pliniusz Starszy w I w. n.e. wspominał w swojej Historii Naturalis o obszarach dzisiejszej Francji i Hiszpanii jako rzymskich prowincjach, w których panowała kultura picia piwa. Znaleziska archeologiczne $\mathrm{z}$ terenów Babilonii w głównej mierze dotyczą produkcji i spożycia piwa, ale potwierdzają także znajomość uprawy winorośli oraz świadczą o uprawianiu winnej latorośli i wytwarzaniu wina na obszarach sąsiadujących od północy z państwem babilońskim prawdopodobnie już od czasów prehistorycznych (Powell 1996, s. 106).

W przeciwieństwie do Babilonii, gdzie zaczęto uprawiać winorośl bardzo wcześnie, choć nigdy nie rozwinięto jej w prawdziwą kulturę picia wina, pierwsze archeologiczne świadectwa uprawy winorośli i produkcji wina nad środkowym Eufratem datuje się na początek XVIII w. p.n.e. Dowody istnienia rzeczywistej produkcji wina są znikome i nie przypominają relacji Ksenofonta o łatwej dostępności wina około 1400 lat później. Głównym obszarem wytwarzania wina wydają się południowe zbocza gór oddzielających wyżyny Anatolii od ziem położonych w dorzeczu Tygrysu i Eufratu. Najlepsze i najdroższe wina pochodziły z zachodu 
i najczęściej stanowiły królewskie prezenty, co potwierdza, że region wokół Aleppo i dalej na południe był już krajem wina.

Kulturę picia wina $\mathrm{w}$ tym przypadku wiąże się jedynie $\mathrm{z}$ warstwą rządzącą Amorytów, ale nie umniejsza to ich znaczenia dla odtworzenia całej historii wina na Bliskim Wschodzie. Amoryci pochodzili z Syrii i przybywając do Mezopotamii przynieśli ze sobą własny, różnorodny bagaż kulturowy m.in. upodobanie do picia wina. Ci „zachodni” - jak określali ich Babilończycy - na krótko przed $2000 \mathrm{r}$. p.n.e. zaczęli pojawiać się częściej w babilońskich dokumentach z imperium Ur, często wymieniani jako osoby na stanowiskach wojskowych. W XVIII w. p.n.e. stali się elitą ludności całej Mezopotamii, zachowali typowe nazwiska Amorytów oraz, jak się wydaje, wciąż cenili ten sam smak wina. Zimri-Lim z Mali wysyłał wino do Babilonu na zamówienie Hammurabiego, który urodził się w szóstym pokoleniu po przybyciu swoich przodków z Syrii do Babilonii, ale wciąż gustował w tamtejszym winie. Znaleziska archeologiczne z Mari sugerują, że Syryjczycy odegrali w Babilonii podobną rolę do tej, którą pełnili Grecy na południu Italii - rozpowszechnili oni kulturę uprawy i produkcji wina. Również Egipcjanie, podobnie jak Babilończycy przedstawiający Syryjczyków jako bandę barbarzyńców, prawdopodobnie zawdzięczali im nie tylko konie i wozy, ale i zwiększone zainteresowanie winem. Możliwe, że kontakty z nimi przyczyniły się do zwiększenia produkcji wina, szczególnie w delcie Nilu w późnej epoce brązu (Powell 1996, s. 114).

W przeciwieństwie do oficjalnych rejestrów królów asyryjskich z epoki brązu, w których nigdy nie wymienia się wina, w IX w. p.n.e. trunek ten stał się na tyle cennym towarem, że składano go w daninach obok innych wartościowych i egzotycznych przedmiotów. Znaleziska archeologiczne wskazują na rozwój uprawy winorośli i produkcji wina szczególnie w górach i na terenach podgórskich rozciągających się od zachodniego Iranu, przez południową Turcję i Syrię do basenu Morza Śródziemnego. Ciągle konsumpcja wina przypadająca na jedną osobę była stosunkowo niewielka, nadal wino znacznie droższe niż piwo, tak więc regularnie pili je ludzie należący do bogatszych warstw społecznych i żołnierze zawodowi (Powell 1996, s. 121).

W czasach państwa nowobabilońskiego rządzonego przez dynastię chaldejską (626-539 p.n.e.) nawet w Babilonii wino zaczyna pojawiać się regularnie w królewskich inskrypcjach i w postaci ofiary składanej bogom. Staje się ono pożądanym towarem importowanym już nie po tak drogich cenach przez bogatsze warstwy społeczne z Damaszku w Syrii. Nieprzypadkowo obserwujemy zjawisko zwiększenia handlu winem na długich dystansach w tym samym czasie co tworzenie się dużych imperiów. Bardzo mało wiadomo o wysokości kosztów za przejazdy w obrębie większych państw, ale z pewnością o wiele trudniej było podróżować w celach handlowych po małych państwach istniejących w epoce brązu. Możliwe, że w jakiejś części wykształcenie się wielkich imperiów na Bliskim Wschodzie przyczyniło się 
do rozszerzenia importu i eksportu wina z bardziej odległych miejsc niż dotychczas. Potwierdza to opowieść Herodota o przesyłce wina przewożonej z Armenii do Babilonii w V w. p.n.e. (Powell 1996, s. 122).

\section{PODSUMOWANIE}

Dzięki wieloletnim badaniom prowadzonym w różnych krajach zebrano wiele informacji dotyczących winorośli. Dotychczasowe analizy naukowe koncentrowały się na zagadnieniach, takich jak: udomowienie winnej latorośli, odtworzenie obszarów występowania dzikiej i uprawnej winorośli, odróżnienie odmian dzikiej i uprawnej oraz ustalenie metod uprawy winnej latorośli i technologii produkcji wina.

Pomimo rozwoju różnych dyscyplin naukowych, współpracy przedstawicieli nauk przyrodniczych, archeologii i historii, początki uprawy winorośli i okoliczności towarzyszące rozwojowi produkcji wina w basenie Morza Śródziemnego nie są nadal całkowicie znane, (Bouby, Marinval 2001, s. 18) chociaż wiemy jak mogło wyglądać uprawianie winnej latorośli i wytwarzanie wina w starożytności. Stwierdzenie to można odnieść także do obszarów Bliskiego Wschodu i Zakaukazia. W zależności od zagadnienia oraz analizowanego obszaru wyniki badań są mniej lub bardziej kompletne. Od strony archeologicznej wygląda to dużo lepiej niż od strony paleobotanicznej ze względu na większą ilość znalezisk, cechy morfologiczne analizowanego materiału pozwalające na zastosowanie zróżnicowanych metod badawczych oraz możliwość zweryfikowania uzyskanych wiadomości na podstawie analizy źródeł historycznych. Problemy, które pojawiają się podczas badań paleobotanicznych najłatwiej opisać na przykładzie konkretnego obszaru geograficznego. Doskonale obrazuje to stan badań archeobotanicznych we Francji. Dzięki pracom archeologicznym odkryto nie tylko warsztaty garncarskie zajmujące się produkcją amfor i innych naczyń służących do przechowywania wina, ale także pozostałości upraw winnej latorośli z czasów rzymskich i przedrzymskich. Do 1999 r. przebadano 32 najważniejsze stanowiska będące winnicami, znalezione na ziemiach dawnej Gallii Narbonensis (Boissinot 2001, s. 45-68).

Pomimo tego że początki uprawy winorośli, proces jej ekspansji w Galii i związanej z tym produkcji wina oraz amfor służących do jego przechowywania oraz handlu winem jest bardzo dobrze udokumentowany pod względem historycznym i archeologicznym, została zebrana duża baza danych archeobotanicznych, morfologicznych i genetycznych - zidentyfikowanie i wykształcenie się kultywarów, historia, biogeografia i mechanizmy udomowienia winnej latorośli pozostają niejasne. Obecnie badania we Francji i innych krajach, w których uprawia się winorośl i produkuje wino ograniczają się do odróżnienia archeobotanicznych pozostałości winogron - dzikich i uprawnych odmian. Niestety dużym utrudnieniem jest brak możliwości porównania z wystarczającą ilością populacji dzikich roślin, kultywarów 
współcześnie występujących, a także znalezienia wystarczająco do nich zbliżonych okazów. Z różnych powodów badania te prowadzi się w skali lokalnej w odniesieniu do małych obszarów lub do regionów (Terral i in. 2010, s. 444).

Pozostałości winorośli odkrywane na stanowiskach archeologicznych poddaje się analizie paleobotanicznej. Najlepiej zachowują się pestki winogronowe. Stanowią one źródło ważnych informacji. Obecnie badania paleobotaniczne opierają się na geometrycznej analizie ich struktury, która ma na celu:

1) ustalenie kryteriów pozwalających odróżnić winorośl dziką od uprawnej,

2) obserwację zmian zachodzących w procesie udomowienia,

3) określenie przedziałów fenotypowej różnorodności dzikich i udomowionych odmian,

4) ustalenie związków pomiędzy kształtowaniem się różnorodnych odmian i gatunków winorośli a geograficzną przynależnością do danego kraju lub regionu i jakie ma to odbicie w analizie genetycznej roślin (Terral i in. 2010, s. 444).

\section{BIBLIOGRAFIA}

Arnold C., Gillet F., Gobat J.M.

1998 Situation de la vigne sauvage Vitis vinifera ssp.silvestris en Europe. Vitis, 37(4), s. 159-170.

Boissinot $\mathrm{P}$.

2001 Archéologie des vignobles antiques du sud de la Gaule. Gallia, 58, s. 45-68.

Bouby L., Marinval P.

2001 La vigne et les débuts de la viticulture en France: apports de l'archéobotanique. Gallia, 58 , s. $13-28$.

Bouby L., Terral J.-F., Figueiral I., Ivorra S., Lacombe T., Pastor T., Picq S., Bouffat L., Fabre L., Jung C., Marinval P., Petitot H., Tardy Ch.

2010 La vigne sauvage (Vitis vinifera subsp. Sylvestris): une plante cultivée dans les établissements viticoles de la Narbonnaise? W: C. Delhon, I. Théry-Parisot, S. Thiébault (red.), Des hommes et des plantes. Exploitation du milieu et gestion des ressources végétales de la préhistoire à nos jours. XXXe rencontres internationales d'archéologie et d'histoire d'Antibes (s. 129-139). Antibes.

Columella L.I.M., Hedberg S.

1968 L.Iuni Moderati Columellae Rei Rusticae liber XII. Uppsala: Eranos’ Förlag

Desfayes M.

1989 La vigne sauvage en Valais. Bulletin Murithienne, 107, s. 161-165.

DiVora A., Castelletti L.

1995 Indagine preliminare sull'archeologia della vite (Vitis vinifera L.) in base ai caratteri diagnostici del vinacciolo. Rivista Archeologica dell'Antica Provincia e Diocesi di Como, 176, s. 333-358.

Gōkbayrak Z., Söylemezoglu G.

2010 Grapevine throughout the History of Anatolia. International Journal of Botany, 6(4), s. $465-472$. 
Jackson R.

2008 Wine science. Principles and applications. Academic Press: Amsterdam.

Jacquat $C$.

1988 Les plantes de l'âge du Bronze. Catalogue des fruits et des grains. Archéologie Neuchâteloise. Hauterive-Champréveyres (Archéologie Neuchâteloise 7). Saint Blaise: Editions du Ruau.

Jacquat C., Martinoli D.

1999 Vitis vinifera L.: wild or cultivated? Study of the grape pips found at Petra, Jordan; 150 B.C. - A.D. 40. Vegetation History and Archeobotany, 8, s. 25-30.

Kislev M.E.

1988 Fruit remains. W: B. Rothenberg (red.), The Egyptian mining temple at Timna (s. 236-242). London: Institute for Archaeo-Metallurgical Studies [and] Institute of Archaeology, University College.

Levadoux L.

1956 Les populations sauvages et cultives de Vitis vinifera L. Annales de l'almélioration des plantes, 1, s. 59-117.

Mangafa M., Kotsakis K.

1996 A New Method for the Identification of Wild and Cultivated Charred Grape Seeds. Journal of Archaeological Science, 23, s. 409-418.

McGovern P.E.

2003 Ancient Wine. The Search for the Origins of Viniculture. Princeton: Princeton University Press.

Nuñez-Rivera D., Walker M.J.

1989 A review of paleobotanical findings of early Vitis in the Mediterranean and of the origins of cultivated grape-vines, with special reference to new pointers to prehistoric exploitation in the western Mediterranean. Review of Paleobotany and Palynology, 61,

Olmo H.P. s. 205-237.

1996 The Origin and Domestication of the Vinifera Grape. W: P.E. McGovern, S.J. Fleming, S.H. Katz (red.), The Origins and Ancient History of Wine (s. 31-43). Amsterdam: Routledge.

Orru M., Grillo O., Lovicu G., Venora G., Bacchetta G.

2008 Morphological characterisation of Vitis vinifera L. seeds by image analysis and comparison with archaeological remains. The Journal of Quaternary Plant Ecology, Palaeoclimate and Ancient Agriculture, 17.6.

Powell M.A.

1996 Wine and the Vine in Ancient Mesopotamia: The Cuneiform Evidence W: P.E. McGovern, S.J. Fleming, S.H. Katz (red.), The Origins and Ancient History of Wine (s. 97-122). Amsterdam: Routledge.

Renfrew J.M.

1996 Palaeoethnobotanical Finds of Vitis from Greece W: P.E. McGovern, S.J. Fleming, S.H. Katz (red.), The Origins and Ancient History of Wine (s. 255-267). Amsterdam: Routledge.

Stummer A.

1911 Zur Urgeschichte der Rebe und des Weinbaues. Mitteilungen der Anthropologischen Gesellschaft in Wien, 61, s. 283-296.

Terral J.-F., Tabard E., Bouby L., Ivorra S., Pastor T., Figueiral I., Picq S., Chevance J.-B., Jung C., Fabre L., Tardy C., Compan M., Bacilieri R., Lacomb T., This P. 
2010 Evolution and history of grapevine (Vitis vinifera) under domestication: new morphometric perspectives to understand seed domestication syndrome and reveal origins of ancient European cultivars. Annals of Botany, 105, s. 443-455.

Unwin T.

1996 Wine and the vine. An Historical Geography of Viticulture and the Wine Trade. London - New York: Taylor \& Francis Ltd.

Walker M.J.

1985 Nuevos datos acerca de la explotacion de la vid en el eneolitivo espagnol. Cuadernos de prehistoria y arqueologia, 11-12, s. 163-182.

Zettler R.L., Miller N.F.

1996 Searching for Wine in the Archaeological Record of Ancient Mesopotamia of the Third and Second Millennia B.C. W: P.E. McGovern, S.J. Fleming, S.H. Katz (red.), The Origins and Ancient History of Wine (s. 123-131). Amsterdam: Routledge.

Zohary D.

1996 The Domestication of the Grapevine Vitis Vinifera L. In the Near East. W: P.E. McGovern, S.J. Fleming, S.H. Katz (red.), The Origins and Ancient History of Wine (s. 23-30). Amsterdam: Routledge.

\section{VITIS VINIFERA SYLVESTRIS AND VITIS VINIFERA SATIVA. THE DOMESTICATION AND DISSEMINATION OF VITICULTURE IN THE OLD WORLD BASED ON ARCHAEOLOGICAL AND PALAEOBOTANICAL RESEARCH}

\section{Summary}

This paper looks at the domestication and spread of viticulture in the Old World and discusses the use of botanical research on the contemporary species of wild and cultivated vine in archaeology. It also discusses such issues as the reconstruction of areas of the occurrence of wild and cultivated vine; distinguishing between wild and cultivated vine species; the determination of the methods of vine growing and wine production technology. The analysis of palaeobotanical remains is possible only when seeds, stems, grape skins, whole fruits and leaves are well preserved. The key to achieve best results is to conduct archaeobotanical analyses of pollen, stems or woody parts of the vine (preferably charred) and seeds, and the ampelographic identification of leaves, a cluster of grapes and single grape berries. The current palaeobotanical research is based on a geometrical analysis of the grape seeds structure. Following A.Stummer's seminal work presenting the biometric index, a number of studies has been published, in which the measurements and indexes were based on such criteria such as the appearance of seeds, rostrum, chalaza and depressions. Particularly interesting were the results of the studies conducted by M. Magafa and K. Kotsakis. 